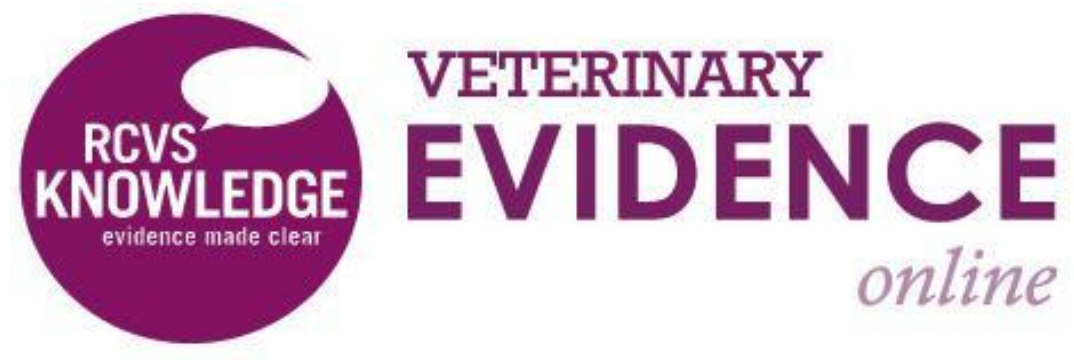

\title{
Evidence Supporting Intralesional Stem Cell Therapy to Improve Equine Flexor Tendon Healing
}

A Knowledge Summary by

Sushmitha Durgam BVSc, MS ${ }^{1}$

Matthew Stewart BVSc, $\mathrm{PhD}^{1^{*}}$

1 University of Illinois, Veterinary Clinical Medicine, Champaign, IL 61801, USA
* Corresponding Author (matt1@illinois.edu)

ISSN: 2396-9776

Published: 3 Jan 2017

in: Vol 2, Issue 1

DOI: http://dx.doi.org/10.18849/ve.v2i1.50

Reviewed by: Wanda Gordon-Evans (DVM, PhD, DACVS-SA, DACVSMR) and Peter Clegg (MA Vet MB PhD CertEO DipECVS MRCVS) 


\section{KNOWLEDGE SUMMARY}

\section{Clinical bottom line}

Current experimental evidence suggests that intralesional stem cell administration improves the histological characteristics and matrix organisation of healing equine superficial digital flexor tendons (SDFT); however, the clinical relevance of these findings are not clear. Current case-based evidence suggests that cell-based therapies improve the quality of tendon healing and reduce the recurrence rates of SDFT injuries but the lack of any randomised, controlled prospective studies with function-based outcomes is still concerning, give the widespread advocacy for and use of 'stem cell' therapies for the treatment of equine tendon injuries.

\section{Question}

Does intralesional stem cell therapy improve healing of equine superficial digital flexor tendons?

\section{The evidence}

To date, equine experimental and clinical case studies of tendon healing demonstrate improved histological and ultrasonographic features of matrix architecture, respectively with intralesional stem cell therapy. These findings encourage clinical use of stem cell-based therapies to enhance equine tendon healing. A few clinical studies indicate that re-injury rates are lower following stem cell treatment, than without. However, these studies do not provide any firm conclusions regarding the ideal cell source for therapy or optimal treatment protocol. Collaborative research and long-term follow up among the veterinary community is needed to establish the optimal applications for cell-based therapies.

\section{Summary of the evidence}

\begin{tabular}{|c|c|}
\hline Del Bue (2008) & \\
\hline Population: & $\begin{array}{l}\text { Clinical cases of superficial digital flexor tendon (SDFT) tendinitis } \\
\text { with a distinct core lesion diagnosed via ultrasonography. }\end{array}$ \\
\hline Sample size: & $\mathrm{n}=16$ \\
\hline Intervention details: & $\begin{array}{l}\text { Intralesional administration of allogeneic adipose-derived } \\
\text { mesenchymal stem cells (Ad-MSCs) suspended in autologous platelet } \\
\text { rich plasma (PRP). }\end{array}$ \\
\hline Study design: & Case series - (no controls, not blinded) \\
\hline Outcome studied: & $\begin{array}{l}\text { Serial ultrasonographic evaluations } \\
\text { Return to exercise/activity }\end{array}$ \\
\hline $\begin{array}{l}\text { Main findings: } \\
\text { (relevant to PICO question): }\end{array}$ & - 14 out of 16 horses returned to activity. \\
\hline Limitations: & $\begin{array}{l}\text { - Small/limited case numbers } \\
\text { - No objective measurements of outcome } \\
\text { - No control groups }\end{array}$ \\
\hline
\end{tabular}




\begin{tabular}{|l|l|}
\hline $\begin{array}{l}\text { Inconsistent follow-up } \\
\text { - Uncertainties regarding the relative contributions of Ad-MSCs and } \\
\text { PRP to outcome }\end{array}$ \\
\hline
\end{tabular}

\begin{tabular}{|c|c|}
\hline \multicolumn{2}{|c|}{ Lacitignola (2008) Experimental study component } \\
\hline Population: & $\begin{array}{l}\text { Clinically healthy Standardbred horses. Pre-existing tendon injury } \\
\text { was ruled out with baseline lameness and ultrasonographic } \\
\text { evaluation. }\end{array}$ \\
\hline Sample size: & Experimental study: $\mathrm{n}=6$ horses ( 24 SDFTs) \\
\hline Intervention details: & $\begin{array}{l}\text { Collagenase-induced tendinitis was created in both forelimb and } \\
\text { both hindlimb SDFTs of four horses, and both forelimb and one } \\
\text { hindlimb SDFTs of two horses. At the time of collagenase injection, } \\
\text { bone marrow aspirates were collected from tuber coxae to isolate } \\
\text { bone marrow-derived MSCs (BMMSC). Bone marrow-derived } \\
\text { mononuclear cells (BMMNC) were isolated from a second bone } \\
\text { marrow aspirate just prior to treatments. Three weeks after } \\
\text { collagenase injections, the SDFT lesions were treated with } \\
\text { autologous BMMSCs ( } 5.5 \times 10^{6} \text { cells) or BMMNCs ( } 1.22 \times 10^{8} \text { cells) re- } \\
\text { suspended in fibrin, fibrin alone or saline. The two injured hindlimb } \\
\text { SDFTs served as sham controls. }\end{array}$ \\
\hline Study design: & Randomised, partially controlled, experimental study; not blinded \\
\hline Outcome studied: & $\begin{array}{l}\text { Semi-objective data: Type lesion score (TLS), fiber pattern score (FPS) } \\
\text { and percentage cross-sectional area of the lesion (\% CSA) at the } \\
\text { maximal injury zone were derived from ultrasonographic evaluations } \\
\text { every 2-3 weeks, up to } 21 \text { weeks after cell administration. } \\
\text { Collagen architecture was assessed in histological sections at } 21 \text { wks. } \\
\text { Collagen types I and III, COMP and CD34 distribution was assessed by } \\
\text { immunohistochemistry }\end{array}$ \\
\hline $\begin{array}{l}\text { Main findings: } \\
\text { (relevant to PICO question): }\end{array}$ & $\begin{array}{l}\text { - At } 8 \text { weeks, cell-treated SDFTs had a decreased lesion size (\% CSA) } \\
\text { compared to controls; however, there was no difference between } \\
\text { BMMSC- and BMMNC-treated tendons. } \\
\text { - At } 16 \text { weeks, \% CSA, FPS, TLS were significantly better in the cell- } \\
\text { treated SDFTs compared to control SDFTs. } \\
\text { - Both cell treatments improved collagen alignment compared to } \\
\text { controls. }\end{array}$ \\
\hline Limitations: & $\begin{array}{l}\text { - Small sample size and low power } \\
\text { - Two of six hindlimb SDFTs were used as the collagenase control } \\
\text { - Uncertainties about 'stem cell' characteristics of primary culture- } \\
\text { expanded BMMSC cell population } \\
\text { - Quantitative data were not presented; only summary statements } \\
\text { - Outcome measures were predominantly qualitative } \\
\text { - Nominal outcome data were misrepresented and improperly } \\
\text { analysed. Significant outcomes were not designated } \\
\text { - Biomechanical or other functional testing were not carried out }\end{array}$ \\
\hline
\end{tabular}




\begin{tabular}{|c|c|}
\hline \multicolumn{2}{|c|}{ Lacitignola (2008) Clinical study component } \\
\hline Population: & $\begin{array}{l}\text { Standardbreds and Showjumpers presented for evaluation and } \\
\text { treatment of SDFT or suspensory ligament injuries. }\end{array}$ \\
\hline Sample size: & $\begin{array}{l}8 \text { STBs, } 12 \text { showjumpers, } 14 \text { SDFT lesions, } 3 \text { suspensory ligament (SL) } \\
\text { body lesions, } 3 \text { SL branch lesions. }\end{array}$ \\
\hline Intervention details: & $\begin{array}{l}1.23 \times 10^{8} \text { BMMNCs in fibrin were injected into the lesions under U-S } \\
\text { guidance. Horses were stall-rested for } 8 \text { weeks, followed by gradual } \\
\text { return to exercise and competition over the following } 20-30 \text { weeks. }\end{array}$ \\
\hline Study design: & Clinical case series; no control group, not blinded. \\
\hline Outcomes studied: & $\begin{array}{l}\text { Ultrasonographic assessment } 3 \text { and } 8 \text { weeks after injections. } \\
\text { Changes in Type lesion score (TLS), fiber pattern score (FPS) and } \\
\text { percentage cross sectional area of the lesion (\% CSA) were recorded. } \\
\text { Time to return to training/racing, and re-injury rates }\end{array}$ \\
\hline $\begin{array}{l}\text { Main findings: } \\
\text { (relevant to PICO question): }\end{array}$ & $\begin{array}{l}\text { - } 3 \text { weeks after treatment (T3), the injury sites were pain-free. } \\
\text { - After } 6 \text { weeks, clinical lameness was resolved in all cases } \\
\text { - } \% \text { CSA, FPS and TLS improved in all patients by week 3, and this } \\
\text { improvement continued throughout the study } \\
\text { - } 12 \text { of } 20 \text { patients }(60 \%) \text { had returned to work. The re-injury rate } \\
\text { was assessed at } 35 \% \text {. }\end{array}$ \\
\hline Limitations: & $\begin{array}{l}\text { - Small case numbers } \\
\text { - No control group } \\
\text { - Variable lesion severities and locations } \\
\text { - Variable follow-up intervals and functional outcome expectations } \\
\text { - No quantitative outcomes were presented; only summary } \\
\text { statements. No statistical analyses }\end{array}$ \\
\hline
\end{tabular}

\begin{tabular}{|c|l|}
\hline \multicolumn{2}{|l|}{ Nixon (2008) } \\
\hline Sopulation: & $\begin{array}{l}\text { Clinically healthy horses of various breeds. Pre-existing tendon injury } \\
\text { was ruled out with baseline lameness and ultrasonographic } \\
\text { evaluation. }\end{array}$ \\
\hline Intervention details: & $\mathrm{n}=8$ \\
\hline Study design: & $\begin{array}{l}\text { Collagenase-induced tendinitis was created in } 1 \text { randomly chosen } \\
\text { forelimb SDFT of all horses. Five days after collagenase injection, } \\
\text { adipose tissue was obtained from gluteal region for isolation of } \\
\text { autologous adipose-derived nucleated cells (ADNCs). Four randomly } \\
\text { chosen horses received intralesional ADNCs in saline and remaining } \\
\text { 4 horses received an equal volume of saline, 7 days after collagenase } \\
\text { injection. All horses were euthanised 6 weeks after treatment. }\end{array}$ \\
\hline $\begin{array}{l}\text { Randomised, controlled, experimental study; unclear whether } \\
\text { analyses were blinded }\end{array}$ \\
\hline
\end{tabular}




\begin{tabular}{|c|c|}
\hline Outcome studied: & $\begin{array}{l}\text { Semi-objective data - serial ultrasonographic evaluations to } \\
\text { determine the CSA and fiber alignment; histological scores for fiber } \\
\text { alignment, inflammatory cell infiltration and vascularity. } \\
\text { Objective data - Biochemical (total DNA, proteoglycan and collagen } \\
\text { contents) and molecular characteristics (collagen type I and III, } \\
\text { COMP gene expression) were measured in ADNC- and saline-treated } \\
\text { SDFTs } 6 \text { weeks following treatment. }\end{array}$ \\
\hline $\begin{array}{l}\text { Main findings: } \\
\text { (relevant to PICO question): }\end{array}$ & $\begin{array}{l}\text { - ADNC improved collagen organisation, in both ultrasonographic } \\
\text { and histological analyses. } \\
\text { - ADNCs decreased inflammatory cell infiltration, suggesting } \\
\text { immunomodulatory effects. } \\
\text { - The biochemical and molecular characteristics of ADNC- and } \\
\text { saline-treated SDFTs were largely similar, except that COMP } \\
\text { mRNA levels were higher in ADNC-injected SDFTs. }\end{array}$ \\
\hline Limitations: & $\begin{array}{l}\text { - Small sample size (although satisfactory power in results were } \\
\text { reported) } \\
\text { - Short time frame, relative to clinical disease } \\
\text { - No biomechanical or other functional outcomes were performed. }\end{array}$ \\
\hline
\end{tabular}

Schnabel (2009)

\begin{tabular}{|c|c|}
\hline Population: & Clinically healthy horses of various breeds. \\
\hline Sample size: & $\mathrm{n}=12$ \\
\hline Intervention details: & $\begin{array}{l}\text { Collagenase-induced tendinitis was created in both forelimb SDFTs } \\
\text { of all horses. Five days after collagenase injection, } 1 \text { SDFT from } 6 \\
\text { randomly chosen horses received } 1 \times 10^{7} \text { autologous BMMSCs and } \\
\text { the other } 6 \text { horses received } 1 \times 10^{7} \text { autologous adenoviral IGF-I } \\
\text { infected BMMSCs (adIGF-BMMSCS). The contralateral SDFT in all } 12 \\
\text { horses was injected with saline. All horses were euthanised } 8 \text { weeks } \\
\text { after treatment. }\end{array}$ \\
\hline Study design: & Randomised, controlled, experimental study \\
\hline Outcome studied: & $\begin{array}{l}\text { Semi-objective data - serial ultrasonographic evaluations; } \\
\text { histological scores (evaluated by } 2 \text { blinded observers). } \\
\text { Objective data - Biochemical and molecular characteristics, } \\
\text { biomechanical properties (elastic modulus, stiffness) were measured } \\
\text { in patient-matched cell-treated and saline-treated SDFTs, } 8 \text { weeks } \\
\text { following treatment. }\end{array}$ \\
\hline $\begin{array}{l}\text { Main findings: } \\
\text { (relevant to PICO question): }\end{array}$ & $\begin{array}{l}\text { - Ultrasonographic evaluations did not demonstrate any difference } \\
\text { between MSC-treated and control SDFTs. } \\
\text { - Histologic scores of both cell treatments were significantly } \\
\text { improved over saline control; however, BMMSC and AdIGF- } \\
\text { BMMSC SDFTs were not significantly different from each other. } \\
\text { - Biochemical and molecular characteristics were statistically } \\
\text { similar among the cell-treated and saline SDFTs. }\end{array}$ \\
\hline
\end{tabular}




\begin{tabular}{|l|l|}
\hline & $\begin{array}{l}\text { - Biomechanical properties - stiffness of both cell-treated SDFTs } \\
\text { was higher than saline SDFT; however, this was not significant. }\end{array}$ \\
\hline Limitations: & $\begin{array}{l}\text { - Short time frame, relative to clinical disease } \\
\text { - Improved healing demonstrated only in histological scores which } \\
\text { was determined via semi-objective data. } \\
\text { - No functional outcomes (apart from biomechanical testing) were } \\
\text { performed. }\end{array}$ \\
\hline
\end{tabular}

\begin{tabular}{|c|c|}
\hline \multicolumn{2}{|l|}{ Watts (2011) } \\
\hline Population: & Clinically healthy horses of various breeds. \\
\hline Sample size: & $\mathrm{n}=8$ \\
\hline Intervention details: & $\begin{array}{l}\text { Collagenase-induced tendinitis was created in } 1 \text { randomly chosen } \\
\text { forelimb SDFT of all horses. Seven days after collagenase injection, } \\
\text { allogeneic fetal-derived embryonic stem cells (ESCS) were injected } \\
\text { intralesionally. Four randomly chosen horses received } 3 \times 10^{6} \text { ESCs } \\
\text { suspended in culture medium and remaining } 4 \text { horses received an } \\
\text { equal volume of culture medium. All horses were euthanised } 8 \\
\text { weeks after treatment. }\end{array}$ \\
\hline Study design: & Randomised, controlled, experimental study \\
\hline Outcome studied: & $\begin{array}{l}\text { Semi-objective data - Serial ultrasonographic evaluations; Magnetic } \\
\text { resonance imaging (MRI) immediately after euthanasia; histological } \\
\text { scores (evaluated by } 2 \text { blinded observers). } \\
\text { Objective data - Biochemical and molecular characteristics were } \\
\text { measured in treated and control SDFT samples, } 8 \text { weeks following } \\
\text { treatment. }\end{array}$ \\
\hline $\begin{array}{l}\text { Main findings: } \\
\text { (relevant to PICO question): }\end{array}$ & $\begin{array}{l}\text { - Ultrasonographic evaluations and histology demonstrated } \\
\text { improved fiber pattern and decreased lesion size in ESC-treated } \\
\text { SDFTs compared to control SDFT lesions. } \\
\text { - MRI did not demonstrate any difference in lesion size or signal } \\
\text { intensity between the treated and control SDFTs. } \\
\text { - Biochemical and molecular characteristics of both groups were } \\
\text { similar. }\end{array}$ \\
\hline Limitations: & $\begin{array}{l}\text { - Improved healing demonstrated only in histological scores which } \\
\text { - } \text { - Shor determined via semi-objective data. } \\
\text { - No biomechanical or other functional outcome data. }\end{array}$ \\
\hline
\end{tabular}




\begin{tabular}{|c|c|}
\hline \multicolumn{2}{|l|}{ Caniglia (2012) } \\
\hline \multicolumn{2}{|c|}{ Population: Clinically healthy horses of various breeds. } \\
\hline Sample size: & $n=6$ \\
\hline Intervention details: & $\begin{array}{l}\text { Core lesions were created in both forelimb SDFTs with a synovial } \\
\text { resector. One randomly chosen SDFT was treated with } 1 \times 10^{7} \\
\text { autologous BMMSCs suspended in BM supernatant, } 4 \text { weeks } \\
\text { following injury. The contralateral SDFT received an equal volume of } \\
\text { BM supernatant only. Horses were euthanised } 12 \text { weeks after } \\
\text { treatment. }\end{array}$ \\
\hline Study design: & Randomised, controlled, experimental study \\
\hline Outcome studied: & $\begin{array}{l}\text { Objective data - collagen fibril diameters were measured in } \\
\text { transverse sections of SDFTs by transmission electron microscopy. } \\
\text { Samples were obtained from healthy and injured regions of each } \\
\text { SDFT. }\end{array}$ \\
\hline $\begin{array}{l}\text { Main findings: } \\
\text { (relevant to PICO question): }\end{array}$ & $\begin{array}{l}\text { - Intralesional administration of autologous BMMSCs did not affect } \\
\text { the collagen fibril diameters of the treated and control SDFTs. }\end{array}$ \\
\hline Limitations: & $\begin{array}{l}\text { - Single outcome measure (collagen fibril diameter) was evaluated } \\
\text { which may not accurately reflect the healing response at } 12 \\
\text { weeks post-treatment } \\
\text { - Short time frame, relative to clinical disease } \\
\text { - No functional outcome assessments. }\end{array}$ \\
\hline
\end{tabular}

\begin{tabular}{|c|c|}
\hline \multicolumn{2}{|l|}{ Godwin (2012) } \\
\hline Population: & $\begin{array}{l}\text { Clinical cases of overstrain-induced SDF tendinitis in thoroughbred } \\
\text { racehorses. }\end{array}$ \\
\hline Sample size: & $n=141$ \\
\hline Intervention details: & $\begin{array}{l}\text { Intralesional injection of } 1 \times 10^{7} \text { autologous BMMSCs in BM } \\
\text { supernatant under ultrasonographic guidance. }\end{array}$ \\
\hline Study design: & Case series - no controls, not blinded \\
\hline Outcome studied: & $\begin{array}{l}\text { Histological evaluation of BMMSC-treated SDFT samples from } 8 \\
\text { horses, } 6-12 \text { months after treatment; evaluators were not blinded. } \\
\text { Long-term follow-up of race records } 2 \text { years after treatment. Re- } \\
\text { injury rates were calculated from information retrieved from } \\
\text { telephone conversations with owners/trainers. }\end{array}$ \\
\hline $\begin{array}{l}\text { Main findings: } \\
\text { (relevant to PICO question): }\end{array}$ & $\begin{array}{l}\text { - Histological evaluation showed lesion repair and collagen crimp } \\
\text { pattern restoration. } \\
\text { - High percentage of cases returned to racing ( } 98.2 \%) \text { with a lower } \\
\text { re-injury rate ( } 27.4 \%) \text { than previously reported in other studies of } \\
\text { conservatively managed cases (46\%). }\end{array}$ \\
\hline Limitations: & - No 'in study' controls. Historical controls were used to determine \\
\hline
\end{tabular}




\begin{tabular}{|l|l|}
\hline & $\begin{array}{l}\text { the benefit of BMMSC therapy in reducing re-injury rates. } \\
\text { - Unavoidable variations in severity of the lesions, intervals } \\
\text { between injuries and therapy, and post-injection } \\
\text { management/training practices }\end{array}$ \\
\hline
\end{tabular}

\begin{tabular}{|r|l|}
\hline \multicolumn{2}{|l|}{ Marfe (2012) } \\
\hline Population: & $\begin{array}{l}\text { Clinical cases of overstrain-induced SDF tendinitis diagnosed with a } \\
\text { distinct core lesion by ultrasonography. }\end{array}$ \\
\hline Sample size: & $\mathrm{n}=6$ \\
\hline Intervention details: & $\begin{array}{l}\text { Intralesional administration of autologous blood-derived stem cells } \\
\text { (BDSCs) in 3 cases. Conventional conservative treatment was } \\
\text { followed in 3 control cases. }\end{array}$ \\
\hline Study design: & Clinical case-control study; not blinded \\
\hline Outcome studied: & $\begin{array}{l}\text { Ultrasonographic evaluation of the injured tendons prior to and } 4 \\
\text { months following BDSC injections. }\end{array}$ \\
\hline Main findings: & $\begin{array}{l}\text { Ultrasonographic evaluation of BDSC-treated cases showed } \\
\text { complete in-fill of the injured site with linear collagen fiber } \\
\text { alignment. } \\
\text { (relevant to PICO question) } \\
\text { Limitations: } \\
\text { fibrous tissue infill at the injured site. }\end{array}$ \\
\hline $\begin{array}{l}\text { Very small group sizes } \\
\text { No objective/quantitative data of treatment outcomes or } \\
\text { statistical analyses }\end{array}$ \\
\hline No long-term follow-up
\end{tabular}

\begin{tabular}{|r|l|}
\hline \multicolumn{2}{|l|}{ Lange-Consiglio (2013) } \\
\hline Population: & $\begin{array}{l}\text { Clinical cases of SDF tendinitis, DDF tendinitis and suspensory } \\
\text { desmitis, diagnosed via ultrasonography. }\end{array}$ \\
\hline Sample size: & $\mathrm{n}=95$ \\
\hline Intervention details: & $\begin{array}{l}\text { Group A - 51 clinical cases treated with } 5 \times 10^{6} \text { allogenic amniotic } \\
\text { membrane-derived mesenchymal cells. } \\
\text { Group B - 44 clinical cases treated with 5 } \times 10^{6} \text { autologous BMMSCs. }\end{array}$ \\
\hline Study design: & Prospective randomised controlled study, not blinded \\
\hline Outcome studied: & $\begin{array}{l}\text { Lameness and ultrasonographic evaluation at monthly intervals for } \\
12-15 \text { months. } \\
\text { Follow-up information on return to previous activity and re-injury, at } \\
2 \text { years after treatment. }\end{array}$ \\
\hline Main findings: & $\begin{array}{l}\text { No major ultrasonographic differences between groups } \\
\text { (relevant to PICO question): } \\
\text { rate (4\%) was lower than BMMSC group } \\
\bullet \text { Group B - returned to work after a recovery period that ranged }\end{array}$ \\
\hline
\end{tabular}




\begin{tabular}{|l|l|}
\hline & between 4-12 months. Mean re-injury rate was higher than Group \\
& A (23.08\%). \\
\hline Limitations: & $\begin{array}{l}\text { - No untreated control group } \\
\text { - Wide ranges of ages, lesion sites and lesion severities, five } \\
\text { performance disciplines that influence outcomes and re-injury } \\
\\
\text { rates }\end{array}$ \\
\hline
\end{tabular}

\begin{tabular}{|c|c|}
\hline \multicolumn{2}{|l|}{ Smith (2013) } \\
\hline Population: & Clinical cases of career-ending SDFT injury. \\
\hline Sample size: & $\mathrm{n}=12$ \\
\hline Intervention details: & $\begin{array}{l}\text { Six randomly selected horses were treated with intralesional } \\
\text { injection of } 1 \times 10^{7} \text { autologous BMMSCs in } 2 \mathrm{~mL} \text { of BM supernatant, } \\
\text { under ultrasonographic guidance. Remaining } 6 \text { 'control' horses } \\
\text { received an equal volume of saline. Horses were euthanised } 6 \\
\text { months following treatment. }\end{array}$ \\
\hline Study design: & Randomised, experimental study; not blinded. \\
\hline Outcome studied: & $\begin{array}{l}\text { Semi-objective data - Ultrasonographic evaluation, histological } \\
\text { scores } \\
\text { Objective data - Biochemical and biomechanical characteristics, } \\
\text { were measured in specimens from treated and control SDFTs, } 6 \\
\text { months following treatment }\end{array}$ \\
\hline $\begin{array}{l}\text { Main findings: } \\
\text { (relevant to PICO question): }\end{array}$ & $\begin{array}{l}\text { - Reduced cross-sectional area of BMMSC-treated SDFTs compared } \\
\text { to saline controls at } 6 \text { months. } \\
\text { - No difference in total collagen content of SDFTs } \\
\text { - DNA and sulfated glycosaminoglycan contents of BMMSC-treated } \\
\text { SDFTs were significantly lower than saline controls and similar to } \\
\text { the contralateral normal SDFT. } \\
\text { - Stiffness of BMMSC-treated SDFT was similar to normal SDFT; } \\
\text { elastic modulus of BMMSC-treated SDFT higher than saline } \\
\text { control but not significantly different. } \\
\text { - Overall, improved histological characteristics of BMMSC-treated } \\
\text { SDFT compared to saline control. }\end{array}$ \\
\hline Limitations: & $\begin{array}{l}\text { - Small group sizes } \\
\text { - These cases had severe/end-stage lesions, which might not be } \\
\text { reflective of responses in less severely injured cases. } \\
\text { - No functional assessment, apart from biomechanical tests }\end{array}$ \\
\hline
\end{tabular}




\begin{tabular}{|c|c|}
\hline \multicolumn{2}{|l|}{ Durgam (2016) } \\
\hline Population: & Clinically healthy American Quarter horses \\
\hline Sample size: & $\mathrm{n}=8$ \\
\hline Intervention details: & $\begin{array}{l}\text { Collagenase-induced tendinitis was created in both forelimb SDFTs } \\
\text { of all horses. At the same time, a small segment of lateral digital } \\
\text { extensor tendon was surgically collected to isolate tendon-derived } \\
\text { progenitor cells (TDPCs). Four weeks after collagenase injections, } 1 \\
\text { randomly chosen SDFT in each horse was injected with } 1 \times 10^{7} \\
\text { autologous TDPCs in } 2 \text { mls of saline and the contralateral SDFT } \\
\text { received an equal volume of saline. All horses were euthanised } 12 \\
\text { weeks after TDPC injections. }\end{array}$ \\
\hline Study design: & Randomised, controlled, experimental study; no blinding \\
\hline Outcome studied: & $\begin{array}{l}\text { Subjective data -collagen and proteoglycan distributions in } \\
\text { longitudinal histological sections } \\
\text { Objective data - Biochemical, biomechanical and molecular } \\
\text { characteristics, measured in both forelimb SDFTs and a normal } \\
\text { hindlimb SDFT, } 12 \text { weeks following treatment. Fourier Transform- } \\
\text { Second-Harmonic Generation (FT-S-HG) assessment of collagen } \\
\text { alignment in longitudinal histological sections. }\end{array}$ \\
\hline $\begin{array}{l}\text { Main findings: } \\
\text { (relevant to PICO question): }\end{array}$ & $\begin{array}{l}\text { - Biochemical and molecular characteristics of the TDPC- and } \\
\text { saline-treated SDFTs were not significantly different. } \\
\text { - Yield and maximal stresses of TDPC-treated tendons were } \\
\text { statistically similar to normal SDFT and higher than saline-treated } \\
\text { tendons; however elastic modulus and stiffness of TDPC-treated } \\
\text { SDFT were significantly lower than normal SDFT. } \\
\text { - Subjectively, the collagen and proteoglycan distributions in } \\
\text { histological sections of TDPC-treated SDFTs were similar to } \\
\text { normal SDFT. These findings corroborated with quantitative FT-S- } \\
\text { HG measurements of collagen alignment. }\end{array}$ \\
\hline Limitations: & $\begin{array}{l}\text { - Hindlimb SDFTs were used as controls } \\
\text { - Small group sizes, although sufficient for statistical significance } \\
\text { - Short time frame, relative to clinical disease } \\
\text { - Biomechanical properties were determined in one-quarter } \\
\text { longitudinal samples of the whole SDFT which may have } \\
\text { influenced the results. } \\
\text { - SDFT lesion site specimens collected for biochemical and } \\
\text { molecular analyses might not be reflective of the entire injury. }\end{array}$ \\
\hline
\end{tabular}

\section{Appraisal, application and reflection}

Tendon injuries in horses range from acute tendon strains to chronic tendinopathy, and are both common and challenging problems in equine performance horse practice. The technique and feasibility of cell-based therapy (isolated from bone marrow) for treating equine SDFT injuries was first reported by Smith et al. $(2003 ; 14)$. Since then, intralesional stem cell therapy, using cells from multiple tissue sources, has become 
common and commercial services are now available to support cell-based therapies in horses. The purpose of this Knowledge Summary was to evaluate the available evidence from studies evaluating the efficacy of stem cell therapies for equine flexor tendon healing.

\section{Appraisal}

Eleven studies were identified that addressed this issue (note that the outcomes from references 2 and 3 were replicated in reference 10. Reference 10 was used to evaluate the collective outcomes from these manuscripts). These papers segregated into two distinct groups; six studies using experimental models of tendinopathy (references 1, 5, 10,12,13 and 17) and six case series of clinical tendinitis patients (references $4,6,9-11$, and 15; reference 10 included data for both groups).

Accepting the focused nature of the question under review, there was a remarkable degree of variability in the source of 'stem cell' used in these studies (bone marrow [7], blood [1], amnion [1], adipose tissue [2], embryonic [1], and tendon [1]), the protocols used to generate the therapeutic cell populations, donorrecipient matching (three allogeneic sources and 9 autologous sources), the diluents used for the cell injections (saline [5], bone marrow supernatant [4], plasma [1], PRP [1], and fibrin/thrombin [1]) and, in the clinical studies, the specific disciplines the patients were engaged in. Collectively, these sources of variation confounded any coherent meta-analysis.

Of the six experimental studies, five used intratendinous collagenase injections to generate SDFT lesions (5, $10,12,13,17)$ while Caniglia et al 2012 (1) created a core lesion with a synovial resector. In only two of these studies, were at least some of the outcome assessments conducted in blinded fashion $(13,17)$. While acknowledging that there are no other accepted alternative models, the extent to which either induced lesion reflects the cumulative tensile strain injury of clinical tendinitis cases is debatable. Self-evidently, neither model is generated by tensile overloading, and our own $(5)$ and other's $(3,16)$ experience with the collagenase model has shown that individual horse's responses to collagenase vary considerably.

Accepting these concerns, in all six experimental studies, cell delivery improved the histological and 'matrix organisation' characteristics of the repair tissue, while the ultrasonographic findings were improved in three of the four studies that used ultrasonography for outcome assessment. In all but one experimental study (reference 5), histological outcomes were determined by a score derived from 'cell and tissue characteristics' grading schemes. There is clearly an element of subjectivity in these analyses, particularly given that only two were carried out in blinded fashion. Of more general concern, although it makes intuitive sense that a 'more histologically normal' repair tissue corresponds to a better functional outcome, the relationship between these outcomes is very poorly defined, particularly since higher level matrix organisation has not been addressed in any study to date.

With the possible exception of Lacitignolo et al 2008 (10; 24 weeks), the experimental studies were conducted over time frames far less (7-16 weeks) than the 'several months' interval generally required for clinical tendinitis cases to resolve. It is possible, and even perhaps to be expected, that many of the significant differences between cell-treated and control samples detected at early time points in the experimental studies disappear over longer time frames, as healing in the 'control' groups catches up.

Only two of the experimental studies $(5,13)$ included biomechanical testing to provide some functional assessment of outcome. However, it is debatable how well single 'tensile load to failure' testing translates to the rapid, submaximal cyclic loading that flexor tendons are subjected to clinically. None of the experimental studies addressed the most clinically relevant issue; namely, do horses with tendinitis perform better after receiving cell-based therapies? The ultrasonographic, histological, biochemical, transcriptional and biomechanical analyses are, at best, indirect indices of 'healing quality' and functional return.

Collectively, outcomes from the experimental studies should be considered as B2 evidence. 
Of the six clinical case series, three had very small case numbers and/or no control group and/or marginal outcome assessments $(4,10,11)$ and can be considered to be little more than anecdotal (grade E) in value. The study by Godwin et al 2012 (6) is substantive by virtue of the large number of cases (141) enrolled in the analyses. There was no control/placebo group in this study; the authors used previously published outcomes from analogous patient groups for comparison. Further, the great majority of Godwin et al's patients (105) were National Hunt horses, and so their outcomes should be confined to this discipline. Accepting this, $98 \%$ of treated horses returned to racing (albeit after an 8+ month layoff) and the re-injury rate (27\%) was approximately half that reported in two studies from similar National Hunt populations. Although the Evidentiary Value of the Godwin study should, at best, be classified as an uncontrolled prospective study (C), the clinical significance of the outcomes is high (grade 1 to 2 ).

Lange-Consiglio et al 2013 (9) compared the responses of 95 performance horses with tendon or ligament injuries randomly assigned to be treated with allogeneic amnion-derived stem cells (AMSC; 51 cases) or autologous bone marrow-derived stem cells (BMMSC; 44 cases) in a fibrin carrier. This study included show jumpers, dressage horses, eventers, trotters and thoroughbreds, with lesions in the superficial and deep digital flexor tendons and suspensory ligaments and a range of clinical signs and lesion severity, although these variables were distributed fairly evenly across both treatment groups. Horses treated with AMSCs returned to training earlier than horses receiving BMMSCs and the re-injury rates were considerably less in the AMSC group (4\%) than the BMMSC group (23\%). The overall BMMSC group re-injury rate was reassuringly similar to the rate reported by Godwin et al, above, although Lange-Consiglio's Thoroughbreds responded substantially better ( $12.5 \%$ recurrence) than Godwin's thoroughbreds $(50 \%)$. The study by LangeConsiglio et al 2013 should be considered B2.

In the final clinical study, by Smith et al 2013 (15), was a prospective, randomised, controlled clinical trial involving 12 horses with end-stage tendinitis. Further, the histological evaluations of the tendon samples were blinded. Although the horses in the study were not exercised above trotting speeds, there were substantial improvements in ultrasonographic, histological and biomechanical characteristics of healing tissue six months after Intralesional BMMSC treatment. From an experimental design perspective, this study provides the most compelling results supporting stem cell use for flexor tendinitis in horses and should be classified as B2.

\section{Application}

From an evidentiary perspective, the collective data supporting cell-based therapy for equine flexor tendinitis is not strong. In this review, we have raised concerns regarding the clinical applicability of the experimental tendinitis models, the relevance of indirect 'healing quality' outcomes to functional success, inadequate or nonexistent control groups and experimental design issues with published clinical trials. The clinical reality is that conventional approaches to managing flexor tendinitis/tendinopathy in performance horses require prolonged and intensive therapy and rehabilitation efforts yet carry a guarded prognosis. Any novel therapeutic option, whether cell-based, biologic or pharmaceutical, will likely be embraced by the equine veterinary community if that option holds some promise of an improved outcome. This perspective makes any attempt to conduct a randomised, controlled, prospective clinical trial challenging, particularly given the funding constraints that veterinary researchers routinely work under.

While acknowledging the questionable evidentiary value of some studies, there is a consistent collective body of evidence supporting the findings that cell-based therapies improve tendon matrix repair and reorganisation, both in experimental and clinical subjects, and significantly reduce recurrence rates following return to work. In light of these conclusions, and the lack of any more promising alternatives, cell-based therapies should be considered for treating equine flexor tendinitis cases and, by extension, for ligament injuries also. As the applications of these therapies evolve, there are many variables that need to be investigated and optimised. Some of the major issues are as follow: 
1. Standardisation/optimisation of cell source(s), cell processing, and diluents

2. Optimisation of timing and dose(s) of cell delivery following injury

3. Agreement on effective post-therapeutic case management and rehabilitation protocols

4. Standardisation of meaningful outcome measures for specific equine disciplines

\section{Conclusions and Reflection}

Cell-based therapy, in both the human and veterinary fields, is a highly dynamic, but poorly defined field of discovery. It is clear that clinical applications of cell-based therapies have far outstripped our understanding of the biological mechanisms by which stem cells influence healing. As noted above, there is little or no rationale for deciding on many of the variables that influence cell-based therapy efficacy. Somewhat contentiously, the actual need for a 'stem cell' population, as opposed to any population of cells isolated from a tissue or fluid, has not been demonstrated through properly controlled experiments. Further, data from recent cell-tracking studies $(5,7,16)$ clearly show that exogenous stem cells are cleared from the injection site within a few weeks and do not contribute to the pool of tenocytes and/or progenitor cell engaged in tendon repair/regeneration beyond this time. It is probable that secreted stem cell cytokines and/or trophic factors contribute substantially to stem cells' impact on tissue repair (8). Identifying these factors could simplify and standardise 'biologic therapy' considerably.

Regardless of the specific biologic therapy in question, randomised, appropriately controlled studies using a consistent and translatable experimental model or clinical caseload, standardised treatment and rehabilitation protocols and credible outcome assessments, will be required to make meaningful headway on clarifying efficacy. Given the costs and case numbers required for these clinical trials, multi-center/practice collaboration and significant financial support from private industry and foundations will be necessary. Depending on regulatory developments in human medicine, the veterinary community might also stand to benefit from biomedical research efforts focused on validating cell-based therapies for people.

\section{Methodology Section}

\begin{tabular}{r|l|}
\multicolumn{2}{l}{ Search Strategy } \\
\hline $\begin{array}{r}\text { Databases searched and dates } \\
\text { covered: }\end{array}$ & $\begin{array}{r}\text { Search terms were applied in PubMed Central accessed on NCBI } \\
\text { website }(1910-2016), \text { CAB abstracts database accessed on OVID } \\
\text { platform (1973-2015) and Scopus }\end{array}$ \\
\hline Search terms: & horse AND tendonitis OR tendinitis OR stem cell OR flexor tendon \\
\hline Dates searches performed: & August 2016 \\
\hline
\end{tabular}

Exclusion / Inclusion Criteria

Exclusion: Non-English language, review articles, case reports, conference proceedings/abstracts

Inclusion: Experimental studies and clinical case series evaluating the effect of intralesional stem cell therapy on equine superficial digital flexor tendon healing. 


\begin{tabular}{|c|c|c|c|c|c|}
\hline \multicolumn{6}{|c|}{ Search Outcome } \\
\hline Database & $\begin{array}{l}\text { Number of } \\
\text { results }\end{array}$ & $\begin{array}{l}\text { Excluded - did not } \\
\text { answer PICO question }\end{array}$ & $\begin{array}{l}\text { Excluded - } \\
\text { review articles }\end{array}$ & $\begin{array}{l}\text { Excluded - not } \\
\text { in English }\end{array}$ & $\begin{array}{c}\text { Total relevant } \\
\text { papers }\end{array}$ \\
\hline $\begin{array}{l}\text { NCBI } \\
\text { PubMed }\end{array}$ & 24 & 11 & 2 & 0 & 11 \\
\hline Scopus & 18 & 8 & 0 & 1 & 9 \\
\hline CAB Direct & 26 & 10 & 0 & 6 & 10 \\
\hline \multicolumn{5}{|c|}{ Total relevant papers when duplicates removed } & 11 \\
\hline
\end{tabular}

\section{CONFLICT OF INTEREST}

The authors declare no conflicts of interest.

\section{REFERENCES}

1. Caniglia, C.J. et al (2012) The Effect of Intralesional Injection of Bone Marrow Derived Mesenchymal Stem Cells and Bone Marrow Supernatant on Collagen Fibril Size in a Surgical Model of Equine Superficial Digital Flexor Tendonitis. Equine Veterinary Journal, 44 (4), pp. 587593. http://dx.doi.org/10.1111/i.2042-3306.2011.00514.x

2. Crovace, A. et al (2007) Cell Therapy for Tendon Repair in Horses: An Experimental Study. Veterinary Research Communications, 31 (S1), pp. 281-283. http://dx.doi.org/10.1007/s11259-007-0047-y

3. Crovace, A. et al (2010) Histological and Immunohistochemical Evaluation of Autologous Cultured Bone Marrow Mesenchymal Stem Cells and Bone Marrow Mononucleated Cells in CollagenaseInduced Tendinitis of Equine Superficial Digital Flexor Tendon. Veterinary Medicine International, 2010, Article ID 250978. http://dx.doi.org/10.4061/2010/250978

4. Del Bue, M. et al (2008) Equine Adipose-Tissue Derived Mesenchymal Stem Cells and Platelet Concentrates: Their Association in Vitro and in Vivo. Veterinary Research Communications, 32 (S2), pp. 51-55. http://dx.doi.org/10.1007/s11259-008-9093-3

5. Durgam, S.S. et al (2016) Tendon-Derived Progenitor Cells Improve Healing of Collagenase-Induced Flexor Tendinitis. Journal of Orthopaedic Research, doi: 10.1002/jor.23251, [Epub ahead of print]. http://dx.doi.org/10.1002/jor.23251

6. Godwin, E.E. et al (2012) Implantation of Bone Marrow-Derived Mesenchymal Stem Cells Demonstrates Improved Outcome in Horses with Overstrain Injury of the Superficial Digital Flexor Tendon. Equine Veterinary Journal, 44 (1), pp. 25-32. http://dx.doi.org/10.1111/j.2042- 


\subsubsection{3.x}

7. Guest, D. et al (2010) Equine embryonic stem-like cells and mesenchymal stromal cells have different migration patterns following their injection into damaged superficial digital flexor tendon. Equine Veterinary Journal, 42 (6), pp. 636-642. http://dx.doi.org/10.1111/j.2042-3306.2010.00112.x

8. Lange-Consiglio, A. et al A (2013) Conditioned Medium from Horse Amniotic Membrane-Derived Multipotent Progenitor Cells: Immunomodulatory Activity in Vitro and First Clinical Application in Tendon and Ligament Injuries in Vivo. Stem Cells and Development, 22 (22), pp. 3015-

3024. http://dx.doi.org/10.1089/scd.2013.0214

9. Lange-Consiglio, A. et al B (2013) Investigating the Efficacy of Amnion-Derived Compared with Bone Marrow-Derived Mesenchymal Stromal Cells in Equine Tendon and Ligament Injuries. Cytotherapy, 15 (8), pp. 1011-1020. http://dx.doi.org/10.1016/i.jcyt.2013.03.002

10. Lacitignola, L. et al (2008) Cell Therapy for Tendinitis, Experimental and Clinical Report. Veterinary Research Communications, 32 (Suppl 1), pp. S33-S38. http://dx.doi.org/10.1007/s11259-008-9085-3

11. Marfe, G. et al. (2012) A New Clinical Approach: Use of Blood-Derived Stem Cells (BDSCs) for Superficial Digital Flexor Tendon Injuries in Horses. Life Sciences, 90, pp. 825830. http://dx.doi.org/10.1016/j.lfs.2012.03.004

12. Nixon, A.J. et al (2008) Effect of Adipose-Derived Nucleated Cell Fraction on Tendon Repair in Horses with Collagenase-Induced Tendinitis. American Journal of Veterinary Research, 69 (7), pp.928937. http://dx.doi.org/10.2460/ajvr.69.7.928

13. Schnabel, L.V. et al (2009) Mesenchymal Stem Cells and Insulin-Like Growth Factor-I Gene Enhanced Mesenchymal Stem Cells Improve Structural Aspects of Healing in Equine Flexor Digitorum Superficialis Tendons. Journal of Orthopaedic Research, 27 (8), pp. 1392-1398. http://dx.doi.org/10.1002/jor.20887

14. Smith, R.K. et al (2003) Isolation and Implantation of Autologous Equine Mesenchymal Stem Cells from Bone Marrow into the Superficial Digital Flexor Tendon as a Potential Novel Treatment. Equine Veterinary Journal, 35 (1), pp. 99-102. http://dx.doi.org/10.2746/042516403775467388

15. Smith, R.K.W. et al (2013) Beneficial Effects of Autologous Bone Marrow-Derived Mesenchymal Stem Cells in Naturally Occurring Tendinopathy. PLosOne, 8 (9), e75697. http://dx.doi.org/10.1371/journal.pone.0075697

16. Sole, A. et al (2013) Distribution and Persistence of Technetium-99 Hexamethyl Propylene Amine Oxime-Labelled Bone Marrow-Derived Mesenchymal Stem Cells in Experimentally Induced Tendon Lesions after Intratendinous Injection and Regional Perfusion of the Equine Distal Limb. Equine Veterinary Journal, 45 (6), pp. 726-731. http://dx.doi.org/10.1111/evj.12063

17. Watts, A.E. et al (2011) Fetal Derived Embryonic-Like Stem Cells Improve Healing in a Large Animal Flexor Tendonitis Model. Stem Cell Research and Therapy, 2 (4), pp. 1-12. 


\section{imm \\ orite}

\section{Intellectual Property Rights}

Authors of Knowledge Summaries submitted to RCVS Knowledge for publication will retain copyright in their work, but will be required to grant to RCVS Knowledge an exclusive license of the rights of copyright in the materials including but not limited to the right to publish, re-publish, transmit, sell, distribute and otherwise use the materials in all languages and all media throughout the world, and to license or permit others to do so.

Authors will be required to complete a license for publication form, and will in return retain certain rights as detailed on the form.

Knowledge Summaries are a peer-reviewed article type which aims to answer a clinical question based on the best available current evidence. It does not override the responsibility of the practitioner. Informed decisions should be made by considering such factors as individual clinical expertise and judgement along with patient's circumstances and owners' values. Knowledge Summaries are a resource to help inform and any opinions expressed within the Knowledge Summaries are the author's own and do not necessarily reflect the view of the RCVS Knowledge.

Veterinary Evidence and EBVM Network are RCVS Knowledge initiatives. For more information please contact us at editor@veterinaryevidence.org.

RCVS Knowledge is the independent charity associated with the Royal College of Veterinary Surgeons (RCVS). Our ambition is to become a global intermediary for evidence based veterinary knowledge by providing access to information that is of immediate value to practicing veterinary professionals and directly contributes to evidence based clinical decision-making.

\section{www.veterinaryevidence.org}

RCVS Knowledge is a registered Charity No. 230886. Registered as a Company limited by guarantee in England and Wales No. 598443.

Registered Office:

Belgravia House

62-64 Horseferry Road London SW1P 2AF 